\title{
Individual Differences in Music Reward Experiences
}

Ernest Mas-Herrero

Cognition and Brain Plasticity Group, (IDIBELL), Barcelona, Spain

Josep Marco-Pallares

University of Barcelona, Barcelona, Spain

Urbano Lorenzo-Seva

Universitat Rovira i Virgili, Tarragona, Spain

Robert J. Zatorre

Montreal Neurological Institute, McGill University, \& International Laboratory for Brain, Music and Sound Research, Montreal, Canada

Antoni Rodriguez-Fornells

Cognition and Brain Plasticity Group, (IDIBELL),

Institució Catalana de Recerca i Estudis Avançats

(ICREA), \& University of Barcelona Barcelona, Spain

Music is one of The most pleasant human experiences, even though it has no direct biological advantage. However little is known about individual differences in how people experience reward in musicrelated activities. The goal of the present study was to describe the main facets of music experience that could explain the variance observed in how people experience reward associated with music. To this end we developed the Barcelona Music Reward Questionnaire (BMRQ), which was administrated to three large samples. Our results showed that the musical reward experience can be decomposed into five reliable factors: Musical Seeking, Emotion Evocation, Mood Regulation, Social Reward, and Sensory-Motor. These factors were correlated with socio-demographic factors and measures of general sensitivity to reward and hedonic experience. We propose that the five-factor structure of musical reward experience might be very relevant in the study of psychological and neural bases of emotion and pleasure associated to music.

Received: June 27, 2012, accepted March 1, 2013.

Key words: sensitivity to music, sensitivity to reward, individual differences, musical reward, music processing
I

T IS GENERALLY AGREED THAT MUSIC IS ONE OF the most pleasurable stimuli and that it has an important role in emotion evocation and mood regulation (Dubé \& Le Bel, 2003; Juslin \& Västfjäll, 2008; Schellenberg, 2003). This is the case even though music, like other aesthetic stimuli, is abstract and does not directly imply any obvious natural advantage, as do other biological reinforcers such as sex or food. It has been empirically demonstrated using behavioral measures that music elicits emotional responses that are accompanied by physiological changes (Altenmüller, Schürmann, Lim, \& Parlitz, 2002; Baumgartner, Esslen, \& Jäncke, 2006; Krumhansl, 1997; Salimpoor, Benovoy, Longo, Cooperstock, \& Zatorre, 2009; Sammler, Grigutsch, Fritz, \& Koelsch, 2007; Sloboda \& Juslin, 2001). In addition, several neuroimaging studies have shown the activation of emotion and reward-related brain networks during pleasurable music listening (Blood \& Zatorre, 2001; Brown, Martinez, \& Parsons, 2004; Koelsch, Fritz, Müller \& Friederici, 2006; Menon \& Levitin, 2005; Mitterschiffthaler, Fu, Dalton, Andrew, \& Williams, 2007; for a review, see Koelsch, 2010). More recent data indicate the involvement of the mesolimbic dopaminergic reward processing in association with musical pleasure (Salimpoor, Benovoy, Larcher, Dagher, \& Zatorre, 2011; for a review, see Zald \& Zatorre, 2011). In addition, several lesion studies have shown the selective involvement of the amygdala and the medial temporal lobe (parahippocampal cortex) in the evaluation of emotional responses to music (Dellacherie, Ehrlé, \& Samson, 2008; Gosselin et al., 2005, 2006; Khalfa, Roy, Rainville, Dalla Bella, \& Peretz, 2008). Thus, the involvement of reward and emotional brain circuits for music could explain the widespread value people assign to music, and may be crucial for understanding why this human activity persists across cultures and generations (Zald \& Zatorre, 2011).

However, even considering the strong emotional impact of music in humans, these affective responses are highly specific to cultural and personal preferences, and large individual differences are observed across individuals in how music is experienced. Indeed, little is known about the sources of this interindividual variability in musical reward experiences, or to what degree the differences in the amount of pleasure experienced in music listening are related to personality variables, or

Music Perception, volume 31, issue 2, pp. 118-138, issn 0730-7829, electronic issn 1533-8312. C 2013 by the Regents of the university of California all RIGHTS RESERVED. PLEASE DIRECT ALL REQUESTS FOR PERMISSION TO PHOTOCOPY OR REPRODUCE ARTICLE CONTENT THROUGH THE UNIVERSITY OF CALIFORNIA PRESS'S RIGHTS AND PERMISSIONS WEBSITE, HTTP://WWW.UCPRESSJOURNALS.COM/REPRINTINFO.ASP. DOI: 10.1525/MP.2013.31.2.118 
other temperamental dispositions, or to individual differences in reward experience in other domains. Thus it is of special interest to understand which sources or latent variables underlie this ability to experience reward and emotion due to musical processing in humans.

Several factors could contribute to the individual differences experienced in music reward. For example, there is general agreement that music is capable of inducing a significant emotional impact in humans (Gabrielsson, 2001, 2010; Juslin \& Västfjäll, 2008; Sloboda, 1992, 2010; Wells \& Hakanen, 1991) and individual differences in this factor might explain to a certain degree the differences observed on the amount of pleasure experienced in music. However, this effect might also be influenced (although not necessarily) by the ability to perceive and decode emotions from music fragments (Gabrielsson \& Juslin, 2003; see Juslin \& Västfjäll, 2008). A second important aspect is the ability of listeners to use music as a mood or hedonic regulator. Current empirical evidence suggests that this might be an important purpose of music listening (DeNora, 1999; North, Hargreaves, \& O'Neil, 2000), used in order to change or release emotions, to enjoy, comfort, or even to relieve stress (Behne, 1997; Juslin \& Laukka, 2003; Panksepp \& Bernatzky, 2002; Pelletier, 2004; Sloboda \& O’Neill, 2001; Zillmann \& Gan, 1997) as well as for relaxation purposes or as a background accompaniment to everyday activities (Chamorro-Premuzic \& Furnham, 2007; Sloboda, 2010). Moreover, music has traditionally been effectively used in rituals (Becker, 2004), and more recently in marketing (Bruner, 1990) or film (Cohen, 2001) in order to manipulate and induce hedonic states in humans. Mood improvement has also been observed in stroke patients after intensive music listening or music performance training in motor neurorehabilitation protocols (Bradt, Magee, Dileo, Wheeler, \& McGilloway, 2010; Rodriguez-Fornells et al., 2012; Särkämö et al., 2008).

A third aspect to bear in mind as a source of individual differences is the strong impact that music has in humans through the capacity to spontaneously and intuitively synchronize our body movements to a rhythm's beat, using simple movements (e.g., toe tapping or head nodding) or more complex ones such as dancing. These activities likely are important because the experience of pleasure induced by the practice of these activities involve the complex coordination of cortical and subcortical somatosensory-motor brain networks (Zatorre, Chen, \& Penhune, 2007).

A further factor could be related to the capacity of music to serve as a magnet for human social activities and for bonding individuals into groups (Cross, 2001;
Freeman, 2000; Mithen, 2005; Panksepp \& Bernatzky, 2002). Indeed, one of the most important adaptative functions of music that is crucial for its evolution might be the ability to promote social contact, an aspect that is evident in all cultures. Social contact might be mediated through the inherent pleasure of sharing music-related activities (concerts, music preferences, cultural events, dancing, etc.). Finally and related to the last issue, large differences are usually observed in the way listeners extract, pursue, share, and seek information regarding specific music pieces, composers, performers, or other information related to music. This interest in "knowing about music" could be reflected in many situations and everyday activities, for example, attending live concerts, talking about one's favorite music, seeking formal knowledge about music (e.g., classes or conferences), trying to learn to play an instrument, or simply increasing the amount of time devoted to music listening. Listeners might as well experience pleasure when recognizing musical quotations or allusions to other works (Huron, 2009). A large-scale survey study in music preferences has recently reported a large variability in how people engage in music-related activities (e.g., attending music events or music listening; North \& Hargreaves, 2007a, 2007b, 2007c; see also Rentfrow \& McDonald, 2010). Recent studies have also shown that shared music preferences create deep social bonds across individuals, increasing the social attraction between them (Knobloch, Vorderer, \& Zillmann, 2000; Lonsdale \& North, 2009; Selfhout, Branje, ter Bogt, \& Meeus, 2009). In sum, several factors among the ones previously listed could explain the differences in music pleasure experienced in humans.

The main aim of the present investigation is to provide a fine-grained description of the facets or factors of music experience that could explain the variance observed in how people experience reward associated with music listening and music-related activities. With that dimensional approach in mind, we first developed a new psychometric measure, the Barcelona Music Reward Questionnaire (BMRQ), which was administered to three groups of participants. Initially we tested a large sample of Spanish participants through an internet application with a large number of test questions (Study 1). The items that comprised the final version of the BMRQ were selected after an exploratory factorial analysis on this sample, in which we considered the following aspects: (a) acquiescence and social desirability biases in each item, (b) discriminability values, and (c) representative meaning of the item for the factor extracted. This new version of the questionnaire was administered to a second large group of Spanish 
students in order to: 1) avoid an initial sample bias (the participation of persons highly interested in music activities); and 2) provide a confirmatory factor solution (Study 2). Third, and with the aim of generalization, we translated and adapted the questionnaire into English, and it was again administered through an internet platform to a large, relatively unbiased international population (Study 3). In this third case, the instructions did not indicate that we were specifically addressing questions in relation to music. Afterwards this English version of the questionnaire was analyzed using confirmatory factor analysis.

A second important question is the degree to which reward-seeking tendencies in music are associated with the capacity to experience reward in other rewardrelated domains (e.g., physical reward experiences). This is an interesting question that might shed some light on the debate about the specificity of the brain mechanisms involved in music processing, and in particular on the involvement of the same reward mechanisms across different type of domains (other biological and drug reinforcers). With that aim in mind, participants in the first and third sample were also requested to answer other similar scales related to the domains of individual differences in the susceptibility to avoid possible negative events (punishments) or the tendency to seek positive experiences or rewards (BIS/BAS scales, Carver \& White, 1994; see also Torrubia, Ávila, Moltó, \& Caseras, 2001), Physical Anhedonia Scale (PAS, Chapman, Chapman, \& Raulin, 1976) and the six facets in which Openness to experience could be decomposed (from the NEO-PI-R, Costa \& McCrae, 1992). Finally, this approach also allowed us to explore the question of whether any individuals exhibit significant musical anhedonia in the absence of more general anhedonic traits.

\section{Method}

STUDY 1: DEVELOPMENT OF THE BARCELONA MUSICAL REWARD QUESTIONNAIRE (MRQ)

The aim of the first study was to develop a short psychometric instrument that includes different facets of music and reward experiences. With that purpose, we initially created a pool of 112 items in order to cover a large range of activities and situations associated with reward and pleasure experiences related to music from which to select a smaller number of appropriate items. The first pool of items was created by the authors based on the theoretical background and information regarding pleasure and music gathered from two focus groups (musicians, nonmusicians). The initial content of the statements related to music experience could be initially categorized in six broad categories: music seeking activities, mood regulation, emotion evocation, sensorymotor behavior, social rewarding experiences, and musical memory. In addition, four items were included as a measure of social desirability and 23 (out of the 112) items were inverted to allow acquiescence control. Each item described situations that participants could experience in their daily life. Participants were requested to indicate the level of agreement with the sentence by using a five-point scale ranging from "fully disagree" (1) to "fully agree" (5). Instructions for participants are provided in the Appendices.

Participants. The questionnaire was administered via an internet application to 804 participants living in Barcelona and nearby areas who voluntarily responded (age range: $18-78$ years old, $33.9 \pm 10(S D), 53 \%$ women, $14 \%$ professional musicians). Professional musicians were those participants that reported themselves as musicians, whom principal job and source of income was music. From the non-professional population, $40 \%$ of participants reported musical studies (mean number of years of study, $6.8 \pm 4.6$ ).

Instruments. In the same internet application, Spanish versions of the BAS/BIS scales (Carver \& White, 1994), Physical Anhedonia Scale (PAS, Chapman et al., 1976) and Openness to experience (Spanish version of the NEO-PI-R, Costa \& McCrae, 1992) were administrated to the participants. The BIS/BAS scale evaluates two general motivational systems underling behavior and affect reactions based on Gray's personality theory (Gray, 1990): the behavioral inhibition system (BIS) which regulates aversive situations by moving away from unpleasant events and the behavioural activation system (BAS), with three subscales (Reward Responsiveness, Drive, and Fun Seeking), which regulate appetitive situations by moving toward desired events. Alpha coefficients for Spanish BIS/BAS are .82 (BIS), .73 (reward responsiveness), .65 (Drive), and .72 (Fun Seeking, Caseras, Ávila, \& Torrubia, 2003). The PAS scale evaluates difficulty in feeling physical and aesthetic pleasure in response to typical pleasurable physical stimuli (food, sex, beautiful scenes, etc.). The Spanish version of the PAS show an alpha coefficient of .92 (Fonseca-Pedrero et al., 2009). Openness to experience (from the NEO-PI-R) is believed to reflect intellectual curiosity, preference for the arts and imagination (Costa \& McCrae, 1992). Alpha coefficients for the Spanish Openness scale of the NEO-PI-R is .77. Alpha coefficients of the different facets are .67 (Fantasy), .53 (Aesthetics), .43 (Feelings), .44 (Actions), .64 (Ideas), and .38 (Values; Romero, 
Luengo, Gómez-Fraguela, \& Sobral, 2002). The participants submitted each questionnaire once they responded to all the items of each questionnaire. They only had access to a new questionnaire once the previous one was completed. There was no limitation of time to complete these questionnaires.

Data analysis. Exploratory factor analysis computed in the study was carried out using MATLAB and FACTOR 8.10 (Lorenzo-Seva \& Ferrando, 2006). For scale analyses, SPSS 17 was used (Nouris, 1999). In order to control response biases, we used the procedure described in Ferrando and colleagues (Ferrando, Lorenzo-Seva, \& Chico, 2009) to control social desirability and acquiescence responding: this method isolates the variance due to social desirability and aquiescent responding in two independent factors. Once the variance due to these response biases was removed from the polychoric correlation matrix, a third factor was extracted using Minimum Rank Factor Analysis (MRFA, ten Berge \& Kiers, 1991). In MRFA the observed variables are decomposed into common parts and unique parts that satisfy the following requirements: the covariance matrices for common and unique parts are positive semidefinite, and the unique-parts covariance matrix is diagonal.

STUDY 2: EXPLORATORY AND CONFIRMATORY FACTOR ANALYSIS OF THE BMRQ

In order to replicate the results obtained on the first study, and to avoid the bias possibly induced by the item selection, we administered the final BMRQ questionnaire with the 20 items (see Appendix A) to a new sample of students from the University of Barcelona.

Participants. Six hundred and five students (68\% women, $20.5 \pm 3.3$ years old) participated in the study. Of those, $25 \%$ reported some musical studies (mean number of years of study, $6.5 \pm 3.7$ ). Participants were students of biology, psychology, biochemistry, and chemistry and responded to the questionnaire in their classrooms.

Data analysis. The sample of 605 participants was split in two halves using the DUPLEX algorithm (Snee, 1977). This algorithm optimally splits data samples in the sense that both subsamples are equally representative of the same population (i.e., all possible sources of variance are enclosed in both subsamples). The first sample was used to conduct an exploratory factor analysis (EFA). The second sample was used to conduct a confirmatory factor analysis (CFA). As both analyses led to the same conclusions, the overall sample was used in a final factor analysis to obtain the factorial weights needed to compute participants' factor scores.

EFA was carried out using MATLAB and FACTOR 8.10 (Lorenzo-Seva \& Ferrando, 2006). CFA was carried out using LISREL 8.5 (Joreskog \& Sorbom, 2001). Finally, for scale analyses, SPSS 17 was used (Nouris, 1999).

In the EFA, the polychoric correlation matrix was computed using 20 items of the new test. As already commented in Study 1, acquiescent response variance could be present in the data. To control the variance due to this response style factor, we applied the procedure proposed by Lorenzo-Seva and Rodriguez-Fornells (2006) to the specific case of non-perfectly balanced scales (see Lorenzo-Seva \& Ferrando, 2009). As we expected to have five content factors, this was the number of factors retained using MRFA. To determine the loading factors related to the five content factors, an oblique semi-specified Procrustean rotation (Browne, 1972) was computed, where the specified values were the loadings on each item that we expected to be zero.

In order to study the replicability of the factor structure obtained in the first half sample, a CFA was performed in the second half sample. First, the variance due to AC was once more partialed out. Unweighted leastsquares estimates were computed from the residual covariance. In order to compute the CFA, a model of five correlated factors was proposed, because this was the model suggested in the EFA previously computed (and explained above). We inspected the pattern matrix obtained in the EFA explained above to select five items (i.e., one item per scale) in order to use them as the best markers of each factor (Ferrando \& Lorenzo, 2000).

STUDY 3: CONFIRMATORY FACTORIAL ANALYSIS OF THE ENGLISH VERSION OF THE BMRQ

In this third study we translated and adapted the questionnaire into English (Appendix AI) and it was again administered through an Internet application. However, the literal translation of one item ("Algunas canciones me ponen los pelos de punta”) has different idiomatic expression in Spanish than English. While in Spanish it is understood as a pleasant sensation, in English, the direct translation ("Some songs make my hair stand on end") usually refers to something frightening. Therefore, in order to solve this translation problem, in the English version we changed this item for a new one that was more general, and equivalently related to the corresponding emotion facet ("I like to listen music that contains emotion"). In the present study, the instructions of the test did not indicate that the study was specifically focussed on music in order to avoid a sampling bias effect 
(e.g., that only people interested in music chose to participate in the internet test). In addition, we controlled this bias by asking participants at the end of the questionnaire whether they were aware that the test had anything to do with music in particular: $73.8 \%$ of participants responded they were not aware that the study had anything to do with music in particular, $17.9 \%$ were aware of that, and $8.3 \%$ did not respond that question.

Participants. The questionnaire was administered by an internet application to 252 participants who voluntarily responded ( $25 \pm 5$ year old, $65 \%$ women). Participants were mostly from Europe ( $82 \%$ of the sample) and North America (17\%). This third sample was significantly older than the second Spanish sample, $t(800)=$ $14.92, p<.001$.

Instruments. In the same internet application, English versions of the BAS/BIS scales (Carver \& White, 1994) and Physical Anhedonia Scale (PAS, Chapman et al., 1976) were administered. Sixteen participants did not respond to these questionnaires.

Data analysis. In order to study the replicability of the factor structure obtained in the Spanish sample, CFA was carried out using LISREL 8.5 (Joreskog \& Sorbom, 2001). The variance due to acquiescence was partialed out. Unweighted least squares estimates were computed from the residual covariance. It was proposed that the model of five correlated factors, as the EFA explained above, supported the present data. As markers for the factors, we used the same markers used in the Spanish sample in Study 2.

STUDY 4: STUDY OF THE PROPERTIES THE SCALES OF THE BMRQ As the results of studies 3 and 4 indicated that the factor structure of BMRQ is equivalent independently of the sample used, we combined the samples of studies 2 and 3. The aim was to obtain the estimates of the factor loadings and factor scores weights based on the largest available sample.

Participants. The 857 participants of studies 2 and 3 were used in the present study.

Data analysis. EFA was carried out using MATLAB and FACTOR 8.01 (Lorenzo-Seva \& Ferrando, 2006). For scale analyses, SPSS 17 was used (Nouris, 1999). In the present study, we replicated the factor analysis carried out in study 1 . The polychoric correlation matrix was computed for the 20 items of the new test, and we applied the procedure to control the variance due to $\mathrm{AC}$ variance response. Five content factors were obtained based on
MRFA, and an oblique semi-specified Procrustean rotation was computed, where the specified values were the loadings on each item that we expected to be zero. In order to assess the agreement between (a) the rotated loading matrix obtained in the analysis and (b) the ideal loading matrix, we computed the congruence index between both matrices. Factor scores were computed following the procedure proposed by ten Berge, Krijnen, Wansbeek, and Shapiro (1999). The mean and standardized deviation of items, and the factor weights required to compute these factor scores, are available by request.

We computed the reliability estimates for the five scales and the total scale on the basis of the factor score reliability (see, for example, Mellenbergh, 1994, formula 22 on page 231). In order to compare the scores obtained by Spanish and English participants, we computed the descriptive statistics of factor scores, and compared the mean with an independent-samples $t$ test. Finally, we computed the Kolmogorov-Smirnov statistic to evaluate whether the score distributions in the population significantly differed from a normal distribution.

\section{Results}

STUDY 1: DEVELOPMENT OF THE BARCELONA MUSICAL REWARD QUESTIONNAIRE (BMRQ)

Item selection. From the overall pool of items different criteria were used to select a final set of 20 items (see Table 1; see Appendix A). Those items with loadings lower than 0.30 in the first estimate or greater than 0.30 in any of two response bias factors (i.e., social desirability and acquiescence) were removed. A second selection of items was performed based on the content and adequacy of the items: those items with ambiguous meanings were removed, and items with very similar content to other items were also removed (the item with lower loading was removed). After the selection of items, four facets of Musical Reward were properly represented: Musical Seeking, Mood Regulation, Emotion Evocation, and Sensory-Motor (see Table 2 for the results of the exploratory factor analysis). Finally, the four items with highest loadings in each facet were selected.

Because of the importance of music activities in the bonding and cohesion of groups of persons in all cultures (Cross, 2001; Freeman, 2000), an additional four items most related to Social Reward were also included for the subsequent version. Eventually, we obtained a set of 20 items related to five facets of Musical Reward that were used in the following studies. It must be pointed out that the selected 20 items showed negligible loading values on the social desirability factors. The 20 items 
TABLE 1. Items Included in the Spanish and English versions Evaluated for the BMRQ.

\begin{tabular}{|c|c|c|}
\hline Facet & Spanish items & English items \\
\hline notional Evocation $^{1,2}$ & $\begin{array}{l}\text { 1. Algunas canciones me ponen los pelos de punta. } \\
\text { 2. Me emociono escuchando ciertas canciones. } \\
\text { 3. Puedo llorar cuando escucho algunas melodías } \\
\text { que me gustan mucho. } \\
\text { 4. Siento escalofríos cuando escucho una melodía } \\
\text { que me gusta. }\end{array}$ & $\begin{array}{l}\text { 1. I like to listen music that contains emotion. } \\
\text { 2. I get emotional listening to certain pieces } \\
\text { of music. } \\
\text { 3. I can become tearful or cry when I listen to } \\
\text { a melody that I like very much. } \\
\text { 4. I sometimes feel chills when I hear a melody } \\
\text { that I like. }\end{array}$ \\
\hline Sensory-Motor ${ }^{1,2}$ & $\begin{array}{l}\text { 1. No me apetece bailar ni con la música que más } \\
\text { me gusta. } \\
\text { 2. La música me hace bailar. } \\
\text { 3. No puedo evitar tararear las canciones que me } \\
\text { gustan cuando las escucho. } \\
\text { 4. Cuando escucho una melodía que me gusta } \\
\text { mucho no puedo evitar mover el cuerpo. }\end{array}$ & $\begin{array}{l}\text { 1. I don't like to dance, not even with music } \\
\text { I like } \\
\text { 2. Music often makes me dance } \\
\text { 3. I can't help humming or singing along to } \\
\text { music that I like } \\
\text { 4. When I hear a tune I like a lot I can't help } \\
\text { tapping or moving to its beat. }\end{array}$ \\
\hline Mood Regulation $^{1,2}$ & $\begin{array}{l}\text { 1. La música me hace compañía cuando estoy solo. } \\
\text { 2. La música me tranquiliza y me relaja. } \\
\text { 3. La música me ayuda a desconectar. } \\
\text { 4. Con la música me puedo desahogar. }\end{array}$ & $\begin{array}{l}\text { 1. Music keeps me company when I'm alone. } \\
\text { 2. Music calms and relaxes me } \\
\text { 3. Music helps me chill out } \\
\text { 4. Music comforts me }\end{array}$ \\
\hline Musical Seeking $^{1.2}$ & $\begin{array}{l}\text { 1. En mi tiempo libre apenas escucho música. } \\
\text { 2. Me informo sobre la música que me gusta. } \\
\text { 3. Busco novedades musicales continuamente. } \\
\text { 4. Me gasto bastante dinero en música y cosas } \\
\text { relacionadas con la música. }\end{array}$ & $\begin{array}{l}\text { 1. In my free time I hardly listen to music. } \\
\text { 2. I inform myself about music I like. } \\
\text { 3. I'm always looking for new music } \\
\text { 4. I spend quite a bit of money on music and } \\
\text { related items. }\end{array}$ \\
\hline Social Reward ${ }^{2}$ & $\begin{array}{l}\text { 1. Cuando comparto música con alguien siento } \\
\text { una complicidad especial con aquella persona. } \\
\text { 2. La música me hace conectar con la gente. } \\
\text { 3. Me gusta cantar o tocar un instrumento con } \\
\text { más gente. } \\
\text { 4. En los conciertos me siento en sintonía con } \\
\text { los artistas y el público. }\end{array}$ & $\begin{array}{l}\text { 1. When I share music with someone I feel } \\
\text { a special connection with that person. } \\
\text { 2. Music makes me bond with other people. } \\
\text { 3. I like to sing or play an instrument with } \\
\text { other people. } \\
\text { 4. At a concert I feel connected to the } \\
\text { performers and the audience }\end{array}$ \\
\hline
\end{tabular}

Notes. ${ }^{1}$ Extracted from the first sample / ${ }^{2}$ Extracted from the second sample

TABLE 2. Results of the Exploratory Factor Analysis in Study 1.

\begin{tabular}{|c|c|c|c|c|c|c|}
\hline Item & MS & $\mathrm{EE}$ & MR & SM & $\mathrm{AC}$ & SD \\
\hline En mi tiempo libre apenas escucho música. $\left({ }^{\star}\right)$ & -0.63 & -0.02 & -0.15 & -0.03 & 0.24 & -0.12 \\
\hline Me informo sobre la música que me gusta. & 0.71 & 0.01 & -0.01 & 0.02 & 0.34 & 0.09 \\
\hline Busco novedades musicales continuamente. & 0.76 & -0.06 & 0.02 & 0.03 & 0.25 & 0.05 \\
\hline Me gasto bastante dinero en música y cosas relacionadas con la música. & 0.63 & 0.13 & -0.06 & -0.07 & 0.37 & -0.01 \\
\hline Algunas canciones me ponen los pelos de punta. & 0.10 & 0.96 & -0.10 & -0.03 & 0.02 & 0.00 \\
\hline Me emociono escuchando ciertas canciones. & -0.03 & 0.65 & 0.18 & 0.08 & 0.00 & 0.07 \\
\hline Puedo llorar cuando escucho algunas melodías que me gustan mucho. & -0.11 & 0.55 & 0.17 & 0.14 & 0.07 & 0.07 \\
\hline Siento escalofríos cuando escucho una melodía que me gusta. & -0.07 & 0.83 & 0.06 & 0.01 & 0.09 & 0.05 \\
\hline La música me hace compañía cuando estoy solo. & 0.26 & -0.01 & 0.54 & 0.08 & -0.15 & 0.10 \\
\hline La música me tranquiliza y me relaja. & -0.06 & -0.03 & 0.57 & 0.06 & -0.10 & 0.07 \\
\hline La música me ayuda a desconectar. & 0.02 & 0.03 & 0.69 & -0.03 & -0.08 & 0.07 \\
\hline Con la música me puedo desahogar. & 0.16 & 0.21 & 0.54 & 0.03 & 0.04 & 0.10 \\
\hline No me apetece bailar ni con la música que más me gusta. $\left({ }^{*}\right)$ & -0.04 & 0.02 & 0.11 & -0.83 & 0.24 & -0.10 \\
\hline La música me hace bailar. & -0.04 & -0.01 & 0.05 & 0.84 & 0.05 & 0.10 \\
\hline $\begin{array}{l}\text { No puedo evitar tararear las canciones que me gustan cuando las escucho } \\
\text { por la radio. }\end{array}$ & 0.04 & 0.16 & 0.10 & 0.43 & -0.07 & 0.11 \\
\hline $\begin{array}{l}\text { Cuando escucho una melodía que me gusta mucho no puedo evitar mover } \\
\text { el cuerpo. }\end{array}$ & 0.00 & 0.03 & 0.03 & 0.80 & -0.03 & 0.14 \\
\hline
\end{tabular}

Note: ${ }^{\star}$ Reversed items; AC: Acquiescence; SD: Social Desirability; MS: Musical Seeking; EE: Emotional Evocation; MR: Mood Regulation; SM: Sensory-Motor 
TABLE 3. Correlations Between the BMRQ Factors and Overall Score with the Openness, BIS/BAS, and Physical Anhedonia Scale (PAS) in Study 1.

\begin{tabular}{|c|c|c|c|c|c|c|c|c|c|c|c|c|}
\hline \multirow[b]{2}{*}{ MRQ factors } & \multicolumn{7}{|c|}{ Openness (NEO-PI-R) } & \multicolumn{4}{|c|}{ BIS/BAS } & \multirow[b]{2}{*}{$\begin{array}{l}\text { Anhedonia } \\
\text { (PAS) }\end{array}$} \\
\hline & Fantasy & Aesthetics & Feelings & Actions & Ideas & Values & Overall & $\begin{array}{l}\text { Bas } \\
\text { Drive }\end{array}$ & $\begin{array}{c}\text { Fun } \\
\text { Seeking }\end{array}$ & $\begin{array}{l}\text { Reward } \\
\text { Respon. }\end{array}$ & BIS & \\
\hline Musical Seeking & $.13^{\star *}$ & $.33^{\star *}$ & $.13^{\star *}$ & .03 & .07 & .00 & $.21^{\star *}$ & $.15^{\star *}$ & $.19^{* *}$ & $.12^{*}$ & .00 & $-.11^{\star}$ \\
\hline Emotion Evocation & .05 & $.36^{* *}$ & $.26^{* *}$ & .03 & .02 & .01 & $.22^{\star *}$ & $.12^{\star}$ & $.22^{\star *}$ & $.28^{* *}$ & $.19^{\star *}$ & $-.21^{\star *}$ \\
\hline Mood Regulation & .06 & $.28^{\star *}$ & $.26^{* *}$ & .00 & .07 & .07 & $.22^{\star \star}$ & $.12^{*}$ & $.17^{\star \star}$ & $.23^{\star *}$ & $.13^{\star *}$ & $-.20^{\star *}$ \\
\hline Sensory-Motor & .02 & $.11^{\star}$ & $.17^{\star \star}$ & $.09^{*}$ & .03 & .08 & $.15^{\star \star}$ & $.10^{*}$ & $.21^{\star *}$ & $.31^{\star *}$ & $.18^{\star \star}$ & $-.31^{\star *}$ \\
\hline Overall & $.10^{*}$ & $.38^{\star *}$ & $.28^{\star *}$ & .06 & .07 & .05 & $.29^{* *}$ & $.17^{\star \star}$ & $.28^{\star *}$ & $.33^{\star *}$ & $.17^{\star \star}$ & $-.30^{* *}$ \\
\hline
\end{tabular}

Note: ${ }^{*} p<.05 ;{ }^{* *} p<.001$

can therefore be considered free of this response bias. However, some of the items showed loading values in the acquiescence factor that were in some cases substantial. For this reason, some mechanism to control acquiescent response bias is advised.

Relation with other measures. Table 3 shows Pearson correlation values between BMRQ (the four facets and the overall scale) and BIS/BAS scales, PAS, and Openness to experience. In the correlation with the PAS we did not include the items that made reference to music rewarding experiences.

All factors and the overall scale of the BMRQ positively correlated with Feeling and Aesthetics facets and the overall measure of Openness to experience, as well as Fun seeking, BAS drive, and Reward responsiveness from the BIS/BAS questionnaire. On the other hand, they were also negatively correlated with PAS scale. In addition all facets except Musical Seeking positively correlated with the BIS scale. Finally, Musical Seeking was also positively correlated with Fantasy and the SensoryMotor factor positively correlated with the Action facet of Openness to experience.

Group and age differences. The four facets were negatively correlated with age, as is shown in Figure 1A: Musical Seeking, $r(804)=-.17, p<.001$; Emotion Evocation, $r(804)=-.15, p<.001$; Mood Regulation, $r(804)=-.13, p<.001$; and Sensory-Motor, $r(804)=$ $-.11, p<.001$. Women presented higher values in the Emotion Evocation, $t(802)=5.63, p<.001$, Mood Regulation, $t(802)=4.34, p<.001$, and SensoryMotor, $t(802)=12.11, p<.001$, factors. In contrast, men reported higher punctuations in the Musical Seeking factor, $t(802)=-3.72, p<.001$.

Finally, we studied differences in the BMRQ factors among three groups of participants with different degrees of musical experience: professional musicians, participants with music training but who were not professional musicians, and participants without music training. One-way ANOVA showed an effect of group in Musical Seeking, $F(2,801)=24.50, p<.001$, and Emotion Evocation, $F(2,801)=8.23, p<.001$, but not in Mood Regulation, $F(2,801)=2.23, p=.11$, or Sensory-Motor factors, $F(2,801)=1.71, p=.19$. As Figure 1 shows, professionals and trained participants presented higher values than untrained participants in Musical Seeking and Emotion Evocation factors. On the other hand, professional musicians presented higher Musical Seeking values than trained participants, $t(387)$ $=5.01, p<.001$, but both presented similar values in the Emotion Evocation factor, $t(387)=1.42, p=.15$.

STUDY 2: CONFIRMATORY FACTOR ANALYSIS OF THE BMRQ

In the second study we aimed to replicate the previous findings regarding the factorial structure of the BMRQ in a new large sample of Spanish participants, including the new facet of Social Reward. We first computed the EFA. The Kaiser-Meyer-Olkin (KMO, Kaiser, 1970) index value was .86. In our data, the KMO value suggested that the correlation matrix was well suited for factor analysis (see Kaiser \& Rice, 1974). The congruence values between the rotated loading matrix and the ideal loading matrix were $.64, .80, .83, .91$, and .93 . Only two coefficients were above the threshold of .85 proposed by Lorenzo-Seva and ten Berge (2006) to conclude that the factor similarity between the rotated loading matrices can be consider as fair. However, we visually inspected the loading matrix and concluded that in general the pattern of salient loadings was as expected, and the low congruence values were mainly due to the fact that some loadings that were expected to be zero substantially differed from zero. This outcome could be due to some extent because our five factors are correlated facets of the general factor (Musical Reward).

Multiple indices of fit were examined to evaluate the adequacy of the model. We observed that the errors 

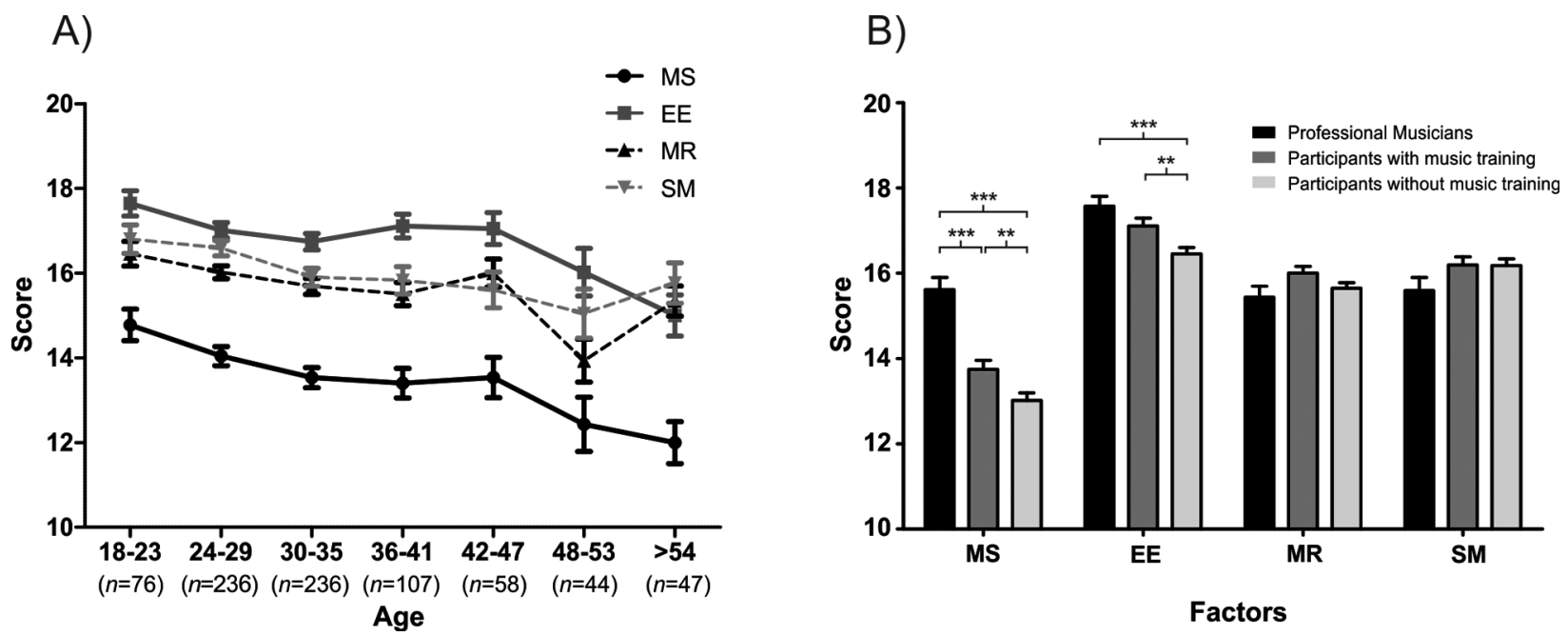

FIGURE 1. Age differences (A) and differences between musicians and nonmusicians (B) in the BMRQ factors in the Study 1. (MS: Musical Seeking; EE: Emotion Evocation; MR: Mood Regulation; SM: Sensory-Motor factor; $\left.{ }^{* *} p<.05 ; * * * p<.01\right)$.

between two items related to different factors were substantially correlated. They were the items "No me apetece bailar ni con la música que más me gusta" (I don't like to dance, not even with music I most like), and "Me informo sobre la música que me gusta" (I inform myself about the music I like). The correlation between the errors were due to the fact that both items share part of the wording (i.e., "la música que me gusta"). We allowed the error of both items to correlate in the model. The values obtained for these indices in our study were CFI $=.99$, GFI $=.99$, and RMSEA $=.07$ (90\% confidence interval .06; .09). Based on these findings, the conclusion was drawn that while the data did not perfectly fit the hypothesized five factors, the fit was nonetheless acceptable.

Group differences. We also studied the differences between participants with and without music training. As we previously observed in Study 1, trained participants presented higher values in Musical Seeking, $t(593)=3.92, p<.001$, and Emotion Evocation, $t(593)=2.44, p<.05$. However, they also reported to experience greater Social Reward, $t(593)=7.31, p<$ .001 . Finally, both groups presented similar values in Sensory-Motor $(t<1)$ and Mood-Regulation, $t(593)=$ $1.40, p=.16$, factors.

STUDY 3: CONFIRMATORY FACTORIAL ANALYSIS OF THE ENGLISH VERSION OF THE BMRQ

The aim of the third study was to generalize the previous findings of the BMRQ in an English-speaking sample, using a confirmatory factorial analysis strategy
(CFA). As in the Spanish sample in Study 2, we observed that the error between two same items were substantially correlated. The English version of these items are "I don't like to dance, not even with music I like," and "I inform myself about music I like." The correlation between the errors is due to the fact that both items share part of the wording (i.e., "music I like"). We allowed the error of both items to correlate in the model, as it was the case in Study 2 with the Spanish sample. The values obtained for the fit indices in our study were $\mathrm{CFI}=.99$, GFI $=.99$, and RMSEA $=$ $.074(90 \%$ confidence interval .062; .087). As can be observed, the fit was quite identical to the one obtained in the Spanish sample (see Results of Study 2 section). Based on these findings, we can conclude that the fit was acceptable and that both sample (Spanish and English) lead to an equivalent factor model.

Relation with other measures. Table 4 shows Pearson correlation values between BMRQ (the five facets and the overall scale) and BIS/BAS scales and PAS. As in the analysis performed with the Spanish sample, we did not include the items that made reference to music rewarding experiences in the PAS scale.

All factors positively correlated with the Reward Responsiveness scale from the BIS/BAS questionnaire. BAS drive was positively correlated with Emotion Evocation, $r(236)=.21, p<.001$, and, on the other hand, BIS was positively correlated with all facets except for Sensory-Motor facet. In addition, Fun Seeking was positively correlated with Sensory-Motor, $r(236)=.19, p<$ .01 , and Social Reward, $r(236)=.14, p<.05$, facets. PAS 
TABLE 4. Correlations Between the BMRQ Factors and Overall Score with the BIS/BAS and Physical Anhedonia Scale (PAS) in Study 3.

\begin{tabular}{|c|c|c|c|c|c|}
\hline \multirow[b]{2}{*}{ MRQ factors } & \multicolumn{4}{|c|}{ BIS/BAS } & \multirow[b]{2}{*}{ Anhedonia (PAS) } \\
\hline & Bas Drive & Fun Seeking & Reward Respon. & BIS & \\
\hline Musical Seeking & .01 & .05 & $.17^{\star \star}$ & $.15^{\star}$ & $-.18^{\star *}$ \\
\hline Emotion Evocation & $.21^{\star *}$ & .11 & $.29^{* *}$ & $.25^{\star *}$ & $-.27^{\star *}$ \\
\hline Mood Regulation & .12 & .13 & $.24^{\star *}$ & $.20^{\star *}$ & $-.24^{\star *}$ \\
\hline Sensory-Motor & .05 & $.19^{* *}$ & $.27^{\star *}$ & .10 & $-.36^{\star *}$ \\
\hline Social Reward & .12 & $.14^{*}$ & $.28^{\star *}$ & $.28^{\star *}$ & $-.28^{\star *}$ \\
\hline Overall & $.14^{*}$ & $.17^{\star \star}$ & $.34^{\star *}$ & $.26^{* *}$ & $-.36^{\star *}$ \\
\hline
\end{tabular}

Note: ${ }^{*} p<.05 ;{ }^{* *} p<.01$

TABLE 5. Loading Matrix Obtained in the Final Factor Analysis.

\begin{tabular}{|c|c|c|c|c|c|c|c|}
\hline Item & & MS & $\mathrm{EE}$ & MR & SM & SR & $\mathrm{AC}$ \\
\hline 11 & I'm always looking for new music. & .86 & -.09 & -.07 & .13 & -.05 & .11 \\
\hline & I inform myself about music I like. & .69 & .10 & .01 & -.07 & .00 & .50 \\
\hline 17 & I spend quite a bit of money on music and related items. & .49 & .14 & -.24 & -.14 & .44 & .16 \\
\hline $2^{*}$ & free time I hardly listen to music. & -.72 & .01 & -.16 & -.02 & .05 & .45 \\
\hline 18 & nes feel chills when I hear a melody that I like. & .00 & .86 & -.02 & -.09 & .03 & .03 \\
\hline 12 & I can become tearful or cry when I listen to a melody that I like very much. & -.04 & .77 & -.20 & .20 & .02 & -.01 \\
\hline 8 & rtain pieces of music. & -.01 & .73 & .18 & -.02 & .02 & .05 \\
\hline 3 & ic that contains emotion. & .08 & .73 & .13 & -.01 & -.17 & .00 \\
\hline 14 & Music helps me chill out. & .05 & .01 & .80 & .07 & .03 & .02 \\
\hline 9 & alms and relaxes me. & -.09 & .11 & .72 & .06 & .11 & .06 \\
\hline 19 & omforts me. & -.08 & .11 & .62 & .05 & .30 & .04 \\
\hline 4 & Music keeps me company when I'm alone. & .23 & .09 & .52 & .07 & -.03 & .01 \\
\hline 10 & Music often makes me dance. & -.03 & -.02 & -.02 & .95 & .01 & .13 \\
\hline 20 & When I hear a tune I like a lot I can't help & .03 & .01 & .11 & .72 & .08 & .02 \\
\hline 15 & ic that I like. & .16 & .07 & .36 & .39 & -.14 & -.14 \\
\hline $5^{*}$ & I don' & .06 & -.09 & .16 & -.87 & -.07 & .29 \\
\hline 13 & ent with other people. & -.01 & .00 & .08 & .05 & .70 & .10 \\
\hline 1 & When I share music with someone I feel a special connection with that person. & .06 & .06 & .18 & -.08 & .61 & .10 \\
\hline 6 & Music makes me bond with other people. & .17 & .00 & .01 & .16 & .58 & .12 \\
\hline 16 & At a concert I feel connected to the performers and the audience. & .18 & -.02 & .20 & .10 & .45 & .13 \\
\hline
\end{tabular}

Note: Loading values that were expected to be salient are printed in bold face. ${ }^{*}$ Reversed items; AC: Acquiescence; MS: Musical Seeking; EE: Emotional Evocation; MR: Mood Regulation; SM: Sensory-Motor; SR: Social Reward (SR).

negatively correlated with all facets. Finally, the overall scale positively correlated with the four scales of the BIS/BAS and negatively with PAS.

STUDY 4: STUDY OF THE PROPERTIES THE SCALES OF THE BMRQ The aim of this last analysis was to pool together the results of the previous studies using the Spanish BMRQ (Study 2) and the English BMRQ version (Study 3) in order to obtain the estimates of the factor loadings and factor scores weights based on the largest available sample.

The Kaiser-Meyer-Olkin (KMO, Kaiser, 1970) index value was .87. Again, the KMO value suggested that the correlation matrix was well suited for factor analysis (see Kaiser \& Rice, 1974). The congruence values between the rotated loading matrix and the ideal loading matrix ranged from .88 to .93 . As the coefficients were all above the threshold of .85, the factor similarity between the rotated loading matrix and the ideal loading matrix was fair (Lorenzo-Seva \& ten Berge, 2006). The values obtained in this final analysis revealed a better fit to the model than the first exploratory factor analysis. Table 5 shows not only the loading values after rotation, but also the loadings of items on the control scale (i.e., the AC). As can be seen in the table, some of the items loaded on the AC scale. These results reinforce our choice of a model where AC response bias style was controlled: because we used this model, the loadings of items on the content factors are free of AC. The loading values on the content factor show that the items were well related with the corresponding expected scale. 
TABLE 6. Interfactor Correlation Matrix.

\begin{tabular}{lcccc}
\hline & Musical Seeking & Emotional Evocation & Mood Regulation & Sensory-Motor \\
\hline Emotional Evocation & .36 & & & \\
Mood Regulation & .42 & .46 & .37 & .21 \\
Sensory-Motor & .28 & .39 & .37 & .22 \\
Social Reward & .35 & .37 \\
\hline
\end{tabular}
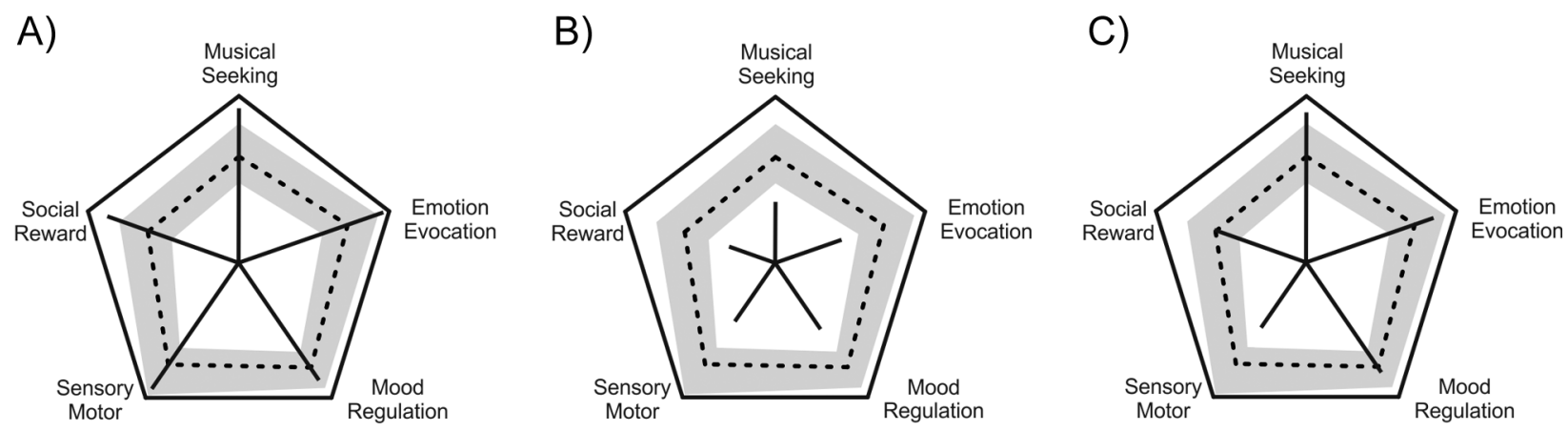

FIGURE 2. Graphical representation of the factor scores of three participants in the present study (the score for each factor is represented as a solid line departing from the center and creating the impression of a star). The dotted line in the middle of the pentagon indicates the mean value of each factor for the general population (Study $4, n=857$ participants), while the surrounding grey area represents one standard deviation above and below the mean value (mean $+S D$; mean $-S D$ ) for each particular factor. In $\mathrm{A}$, we represent a prototypical highly music-hedonic participant, while in $\mathrm{B}$, a music-anhedonic participants is depicted. The participant represented in $\mathrm{C}$ shows normal values in Emotion Evocation, Mood Regulation, and Social Reward and extreme values in Musical Seeking and the Sensory-Motor factors.

Finally, Table 6 shows the interfactor correlation matrix related to content factors. As can be observed, the correlation values between content factors ranged between .21 and .46 . As the scales were actually correlated, it seemed reasonable to compute not only the scores in the five factors, but also in the overall scale. We labeled the factors as Musical Seeking (MS), Emotion Evocation (EE), Mood Regulation (MR), SensoryMotor (SM), and Social Reward (SR). In addition, we labeled the overall scale as Musical Reward (MR).

We computed the reliability estimates on the basis of the factor scores for the scales. The reliabilities were .89, $.88, .87, .78$, and .93 for Musical Seeking, Emotion Evocation, Mood Regulation, Social Reward, and SensoryMotor, respectively. Only the reliability of Social Reward was slightly under the threshold of .80. Finally, we computed reliability of the overall test (i.e., Music Reward) and showed an acceptable reliability (.92).

These five factors allowed us to create a graphic profile of reward music experience for each participant. Figure 2 shows this profile for three different participants. Some participants present high values for all the five factors (Figure 2a), while others might show small values in all the factors (Figure 2b). These latter participants might then present musical anhedonia or impairment in music reward processing. As an example, in Figure 2c a participant could show a large score in the Musical Seeking factor and a small value in the SensoryMotor facet.

In addition, we also analyzed gender differences with both samples combined. Women presented higher values in the Emotion Evocation, $t(838)=6.89, p<.001$, the Mood Regulation, $t(838)=3.58, p<.001$, the SensoryMotor, $t(838)=7.73, p<.001$, and the Social Reward, $t(838)=1.97, p<.05$, factors. However, no differences were reported in the Musical Seeking $(t<1)$ factor.

It should be noted that in order to control acquiescence responding variance, individuals' scores on the test must be obtained using factor score estimates. Factor scores were computed following the procedure proposed by ten Berge et al. (1999). The values of reliabilities of factor scores ranged from 0.78 (Social) to 0.93 (SensoryMotor). Table 7 shows the descriptive statistics of factor scores. We provide an Excel file (www.brainvitge.org/ bmrq.php) for the transformation of raw scores into factors scores. Because of the small number of items composing each factor, it is recommended to transform the values into factor scores instead of using the raw addition of item scores composing the factor (Ferrando, 2012). 
TABLE 7. Descriptive Statistics of Factor Scores for Both Samples in Each Factor and Overall BMRQ Measure + Raw Mean Additive Score of the Overall Scale.

\begin{tabular}{|c|c|c|}
\hline & \multicolumn{2}{|c|}{$\begin{array}{c}2^{\text {nd }} \text { and } 3^{\text {th }} \text { sample } \\
\quad(n=857)\end{array}$} \\
\hline & Mean & $S D$ \\
\hline Musical Seeking & 50.02 & 10.00 \\
\hline Emotional Evocation & 49.98 & 10.00 \\
\hline Mood Regulation & 49.99 & 10.03 \\
\hline Sensory-Motor & 49.94 & 10.01 \\
\hline Social Reward & 50.00 & 10.01 \\
\hline Overall Music reward & 49.98 & 10.01 \\
\hline Overall Music reward ( $\sum$ items) & 78.42 & 10.47 \\
\hline
\end{tabular}

Note: $S D=$ Standard Deviation. Overall Music Reward score ( $\sum$ items) was computed with a raw addition of all 20 -item participants' responses (reverting the scores in items 2 and 5).

Finally, and for the sake of comparison with future studies using different samples or individual persons, we computed the overall score of the BMRQ (adding the raw scores of the items except 2 and 5 , which need to be reversed) (Table 7).

\section{Discussion}

The aim of the present study was to describe the main facets that characterize musical reward experience as well as to develop a reliable questionnaire to study individual differences on such facets and overall sensitivity to music. With this aim in mind, we first created a pool of items related to musical experiences and administered these questions to three different samples. Using exploratory and confirmatory factor analysis, we extracted five latent variables of Musical Reward experiences: Musical Seeking, Mood Regulation, Emotion Evocation, Sensory-Motor and Social Reward. These facets were highly reliable in two different Spanish and English speaking samples, suggesting that the final questionnaire is reliable and consistent within each sample and across different populations.

Similar questionnaires have been developed in order to assess individual differences to overall sensitivity to reward experiences (BIS/BAS, Carver \& White, 1994; Sensitivity to Reward/Sensitivity to Punishment Questionaire, Torrubia et al., 2001). However, music is considered-as other abstract pleasures (such as monetary reward) - to be a higher-order pleasure that may require further or different processing than more basic rewards (e.g., sex and food), even though they may share similar brain mechanisms (Berridge \& Kringelbach, 2008; Blood \& Zatorre, 2001; Menon \& Levitin, 2005; Salimpoor et al., 2011). But contrary to money, reward associated with music has not been traditionally related to its capacity to provide primary reward. In this regard, some authors (Miller, 2000) have suggested that music has a sexual-selection origin similar to the songs produced by songbirds. According to these authors, music would act as secondary reinforcer related with sexual reward. However, given the many situations of real-life music listening where a sexual selection hypothesis could not apply, other factors must clearly play a more important role. Recent studies suggest that the hedonic impact of music listening is driven by its intrinsic ability to evoke emotions (Salimpoor et al., 2009, 2011). Individual differences in the hedonic impact of music emotional experience are clearly represented by the Mood Regulation and Emotion Evocation factors in the BMRQ. However, music listening may also be rewarding in some contexts independently of whether or not music evokes an emotion by itself. For instance, some studies have revealed that social bonds are enhanced by music (Boer et al., 2011; Cross \& Morley, 2009) and that sharing music preference may increase social attraction (Boer et al., 2011). On the other hand, coordination of movements in a group while playing or dancing together leads to increased social cohesion of a group (Cross \& Morley, 2009). Hence, music provides a context in which social interactions take place and, therefore, also leads to social pleasure. Another characteristic of music is that people usually spontaneously synchronize and coordinate body movements to a rhythm's beat by simple (tapping, humming, etc.) or complex movements (dancing) (Brown, Martinez, \& Parsons, 2006). Dance is an ancient human behavior present in all cultures (Farnell, 1999) and many people experience great pleasure while dancing. Hence, dancing and coordination of movements with music may also underlie the rewarding aspects of music. In line with this result, a recent study has also shown individual differences in dance engagement and in the effect of music on exercise performance (Chin \& Rickard, 2012).

The identification of all these latent variables that determine the variability observed in music reward experiences might be crucial for different aspects of music-related behaviors and effects. For example, a recent study has provided evidence that music listening can enhance cognitive recovery and prevent depressive symptoms in a general acute stroke population (Särkämo et al., 2008). In addition, several rehabilitation programs supported by music for stroke patients, such as the Musical Supported Therapy (Rodriguez-Fornells et al., 2012; Rojo et al., 2011; Schneider, Schönle, Altenmüller, \& Münte, 2007) have recently provided successful results. Interestingly, these kinds of therapies have 
been observed to improve not only motor skills, but also mood symptoms (Rodriguez-Fornells et al., 2012; Rojo et al., 2011). Other studies have also reported improvement in depressive symptoms in healthy volunteers (Gupta \& Gupta, 2005; Harmat, Takács, \& Bódizs, 2008) and patients with Alzheimer's dementia (Guetin et al., 2009). Moreover, Soto and colleagues (Soto et al., 2009) reported a decrease of visual neglect when individuals with chronic visual neglect were listening to their preferred music. The authors suggested that this improvement of attentional function was modulated by the positive emotion induced by music. Similar results have been observed when inducing positive affect in healthy volunteers (Rowe, Hirsh, \& Anderson, 2007). Therefore, the emotions evoked by music may improve not only mood symptoms but also cognitive functions. In this sense, it might be important to assess individual differences in music preference and reward sensitivity to music experiences (using the BMRQ) in order to predict the success of music therapy in a particular patient.

In addition, we also studied how these music reward factors are modulated by age, musical experience, and gender. The first two factors were characterized only in the first Spanish sample and without including the Social Reward scale that was clearly identified in the last two studies. Our results suggest that the mean values of the four factors (Musical Seeking, Mood Regulation, Emotion Evocation and Sensory-Motor) decline with age. We also observed this decline in another scale related with individual differences in reward-seeking: the BIS/BAS scale, as has been previously reported (Jorm et al., 1998). However, we have to take into account that this is a cross-sectional study. One limitation of these studies is that age differences may be confounded with differences in generations or cohorts. For instance, nowadays, music is more accessible (i.e., by internet) than 20 years ago. In addition, a second limitation of this study was that ages were not equally represented. That is, the differences reported here cannot be definitively explained by maturation effects. On the other hand, professional musicians and participants with musical studies presented higher values in the Emotion Evocation and Musical Seeking factors. As expected, these subgroups might experience more intensive emotional states with music, seek more information related to music, and listen to music more often than untrained participants. Finally, and concerning gender differences, women presented higher values than men in all facets except in the Musical Seeking factor. However, while in the first sample men reported greater Musical Seeking behavior than women, no differences were observed when second and third samples were combined. Therefore, gender differences on this factor have to be interpreted with caution. Several studies have revealed differences in personality traits (assessed by NEO-PI-R; Costa \& McCrae, 1992) between women and men that are in line with our results (Costa, Terracciano, \& McCrae, 2001; Weisberg, Deyoung, \& Hirsh, 2011). Women score higher in Gregariousness (related with sociability), Positive Emotions (linked to sensitivity to rewards), and Aesthetic and Feeling factors (which, as we discuss below, are related to emotion responsiveness to aesthetics). In contrast, men used to score higher on Excitement Seeking (Costa et al., 2001; Weisberg et al., 2011). These results provide evidence for the external validity of the BMRQ.

However, although we assume that most of the individual differences in musical reward experience are captured by the BMRQ, it is possible that further studies could identify other potential sources of individual differences in experiencing musical reward associated with other functions and uses of music in people's life. Notice that a large overlap might exist between those aspects: music-reward dimensions and the study of why and how people experience music in everyday life (musicuses and functions) (Juslin \& Laukka, 2004; Sloboda, 1999), in the sense that many of the uses or functions of music could represent sources of pleasure. The approach used in investigations of music uses comes originally from sociology and mass media research (Katz, Blumer, \& Gurevitch, 1974) and usually ask participants to report the reasons for using a particular media. In an interesting study using this methodology (Lonsdale \& North, 2011), the authors identified that the most important reason for listening to music was mood regulation, as well as diversion to distract from everyday boredom or simply pass the time. The other less important reasons comprised social functions of music (i.e., "interpersonal relationships" and "personal identity") and the last aspect was the use of music as a means to learn about others and the world around us (i.e., "surveillance"). These factors overlap to a certain degree with a similar study in which Laukka (2007) identified four main motives of music use: 1) identity and agency, 2) mood regulation, 3) relaxation a company, and 4) enjoyment. The complementary study of musical experiences in which peak or very intense emotional reactions are elicited could also complement our study as these experiences are very important for continued involvement in music activities (Gabrielsson, 2011; Sloboda, 2005). Large individual differences have been observed in these studies, as not all individuals are equally prone to experience musical peak experiences (Whaley, Sloboda, \& Gabrielsson, 2009). 
Several questionnaires have been developed to provide the main dimensions of specific music uses and functions. They include items and factors that are very similar to the ones included in our sample pool and proposed facets. For instance, the 15 -item Uses of Music Inventory by Chamorro-Premuzic and Furnham (2007) identified three major music uses in a large sample of participants: 1) intellectual satisfaction (analyzing complex musical compositions), 2) emotional regulation, and 3) the use of music as a background for performing other activities (see for a similar result, Hargreaves \& Colman, 1981). For example, the item "Listening to music really affects my mood" (Chamorro-Premuzic \& Furnham, 2007) could be clearly related to the content of the items evaluated in our BMRQ Mood Regulation facet, while the item "I enjoy listening to music in social events" might be related to the Social facet. Notice, however, that the content in the Intellectual factor (e.g., "I seldom like a song unless I admire the technique of the musicians") is not well represented in any of the facets of our questionnaire. This factor likely represents a more intellectual approach of music experience that could emerge as a possible dimension of music-reward if a more homogeneous sample of trained musicians or music professionals is used. Previous music training and knowledge could allow listeners in these population to focus in different features; for example, the quality of music interpretation, the structure of the composition, and the examination of the score and parts played by different instruments.

Similarly, other authors have pointed out the utilization of music activities and music listening for effective emotional regulation (self-regulation, DeNora, 1999; North et al., 2000), the establishment of self-identity (North et al., 2000), and the creation of interpersonal bonds (North \& Hargreaves, 2007a, b, c). In a recent study, Chin and Rickard (2012) developed a self-report questionnaire (MUSE) and identified five sources of individual differences in musical engagement: engaged production, cognitive regulation, mood regulation, physical (dance and exercise), and social uses of music. Importantly, some factors identified in the BMRQ are very similar to the ones proposed in the MUSE Questionnaire. Specifically, the Mood Regulation, Social, and Sensory-Motor factors of the BMRQ have their counterparts in the MUSE with the Cognitive and Emotional Regulation factor, Social Connection, and Dance. Notice, however, that the Sensory Motor component of BMRQ is not solely represented by dancing. Furthermore, the 53-item Brief Music Experience Questionnaire (Werner, Swope, \& Heide, 2006) also assesses various aspects of music experiences. This instrument comprises six subscales "innovative musical aptitude" (ability to create musical themes), "commitment to music" (pursuing musical experiences in the person's life), "social uplift" (the experience of being stirred and uplifted in a group-oriented manner by music), "affective reactions" (affective and spiritual reactions to music), "positive psychotropic effects" (individual's state of mental reactions, e.g., calming, energizing, integrating reactions), and "reactive musical behavior" (behavioral responses to music, including humming, swaying, etc.). Further analysis showed that these six subscales could be grouped into two factors: Subjective/Physical reactions and Active involvement.

In sum, the close overlap between the facets identified in the BMRQ with the previous proposals related to the study of music functions and use guarantees that our initial item-sampling and the factorial analysis conducted were able to capture most of the variance observed when people experience reward and pleasure associated with music. However, further research is needed to clarify the relationship between music uses/ functions and reward-hedonic experiences associated with music processing. In this regard, the main aim of the development of the questionnaire (and based on previous research related to the neurophysiological evidence linking the mesolimbic dopaminergic reward system and music listening; Salimpoor et al., 2011) was to identify those dimensions of individual differences that explain most of the variance associated with music uses, and related-activities that might induce hedonic pleasure and have an impact on an emotional level. Thus, the objective is less to provide an exhaustive list of all possible situations, contexts, uses, or functions of music, but to provide the main sources or latent variables (facets of the BMRQ) that explain the large individual differences in our ability to experience reward and emotion due to musical processing in humans. Indeed, as suggested in Chin and Rickard (2012; see also, Sloboda, 2005), music engagement is highly tied to motivation, which in turn is related to reward processing both anatomically in the brain (motivation circuit is part of the reward processing network; for a review, see Camara, Rodriguez-Fornells, Ye, \& Munte, 2009) and at the behavior level (Deci, Koestner, \& Ryan, 1999). Therefore, several music uses and possible new uses in the future of music could be closely related to their rewarding properties and could be grouped under the five-dimension umbrella of the BMRQ. However, it is also plausible that some aspects of music use could not be directly mapped onto the sources of individual differences in reward and music identified here. For example, using music for social identity purposes and to communicate and convey 
values, attitudes, and self-views in different cultures (North et al., 2000; Tarrant, North, \& Hargreaves, 2000) might not be initially tied or related to rewarding aspects of music as the ones described here. However, disentangling the effects of music preferences, music uses, and reward is important, as for example, it has been proposed that the selection of particular music preferences could be used in order to reinforce one's views and one's identity (Rentfrow \& Gosling, 2003), thus linking music to possible indirect reinforcement effects affecting cognitive-emotional processes. Future music-modern uses and interpretation using new technologies could also change or modify the type of pleasures that could be evoked by music. Further studies could explore the relation between music uses, preferences, and styles previously described (Chamorro-Premuzic \& Furnham, 2007, Gabrielsson, 2011; Sloboda, Lamont, \& Greasley, 2009; Werner et al., 2006) and its relation to the five dimensions of music-reward identified in the present study. Indeed, music related pleasures are multidimensional (Huron, 2009) and could also be associated with the activation of specific as well as overlapping neurophysiological systems.

The second aim of this work was to study the extent to which reward-seeking tendencies in music (measured by BMRQ) are associated with individual differences in other reward-related domains (measured by Reward Sensitivity measures, Physical Anhedonia, and Openness scales). Previous studies have already observed that individual differences in personality and temperamental dimensions play an important role in music preferences, exposure to different genres, music listening habits and the use of music (Chamorro-Premuzic \& Furnham, 2007; Juslin, Liljeström, Västfjäll, Barradas, \& Silva, 2008; Nusbaum \& Silvia, 2010; Rentfrow \& Gosling, 2003; Rentfrow \& McDonald, 2010). For example Nusbaum and Silvia (2010) showed that Openness to experience predicted music preferences, breadth of musical tastes, and reasons for listening to music in daily life (see also Chamorro-Premuzic \& Furham, 2007; Rentfrow \& McDonald, 2010). In the first Spanish sample, we observed that Openness to experience was positively correlated with all the BMRQ factors. Interestingly, Aesthetics and Feeling facets of Openness to experience were the scales more associated to the BMRQ. Individuals who generally score higher in these two facets tend to be particularly sensitive to art and beauty and experience a wide range of feelings and emotions. In this sense, McCrae (2007) reported that the ability to experience aesthetic chills, which are one of the physiological responses reported with pleasant music (Salimpoor et al., 2009), are specifically related to these two facets.
On the other hand, both reward sensitivity scales, BIS and BAS were positively correlated with the BMRQ. According to Gray's (1990), the BAS scale measures responses to rewarding or appetitive stimuli. In agreement with this, those individuals who score high on the three subscales of this domain are generally more attracted to musical reward. In contrast, the BIS scale mediates responses to aversive stimuli. Individuals who score high on this scale are more likely than average to experience anxiety when faced with negative or painful outcomes (Gray, 1990). A previous study also reported that those individuals are more likely to use music as a mood regulator (Chamorro-Premuzi \& Furnham, 2007). Interestingly, several fMRI studies have found a deactivation of the amygdala while listening to pleasant music (Blood \& Zatorre, 2001; Koelsch et al., 2006). Zald and Zatorre (2011) proposed that pleasure of music could be mediated by two different mechanisms: positive engagement of the reward circuit and inhibition of brain areas mediating negative affective states. Following this reasoning, correlation of both BIS and BAS factors with sensitivity to music could also be explained by this double effect: anxious participants seek and enjoy music because it allows them to inhibit negative states, while in more sensitive to reward participants music engages reward-related brain areas circuit.

Finally, the PAS scale, related with physical anhedonia, was negatively correlated with BMRQ factors and its overall score. That is, the greater the inability to experience pleasure, the lower the ability to experience musical reward experiences (see Figure 3). The anhedonia scale also included several items related to the hedonic impact of music; however we ensured that the effects reported were obtained removing those items from the overall anhedonia score used for the correlation analysis. Despite the fact that the BMRQ and anhedonia (PAS) scales were inversely related, participants with low BMRQ scores did not necessarily show high anhedonia values in all cases (see Figure 3). In Figure 3 we show that about $5.5 \%$ of participants (in both samples from the first and third studies) had low values of music reward sensitivity while having normal values in the anhedonia scale (non-anhedonic participants). These results suggest that musically pleasant experience is (partially) dissociable from physically rewarding experiences. It remains to be seen if this represents a music-specific anhedonia or reflects perceptual difficulties as in congenital amusia (Ayotte, Peretz, \& Hyde, 2002). It is interesting to note, however, that some brain-damaged patients have been reported to present an impaired capacity to experience emotions specifically associated with music, which could be considered a form 

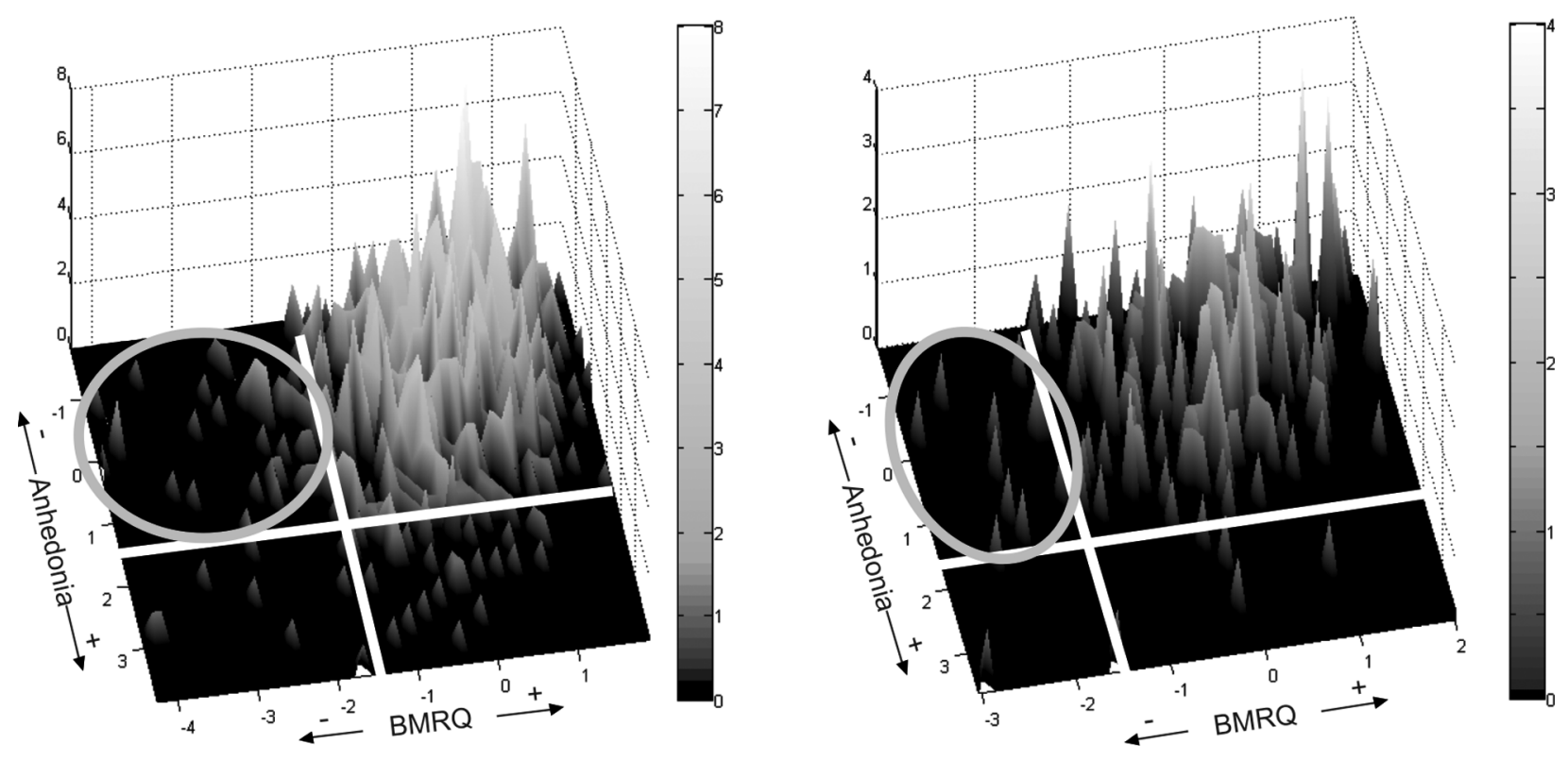

FIGURE 3. Three dimensional display showing the scatterplot between BMRQ and Physical Anhedonia Scale (PAS) scores in the (a) first and (b) third samples. The scores of each participant in both dimensions have been normalized ( $z$-scores represented at both $x$ - $y$ coordinates). The number of participants in each location of the scatter is represented as an increase in the elevation of the cone ( $z$-coordinate, grey scale at the right side; lighter colors represented larger number of participants). Notice that as expected considering the negative correlation between the BMRQ and the PAS, most of the participants are represented in the right upper part of the scatterplot, showing non-anhedonic physical scores in parallel with high hedonic music scores. Importantly for the present study, the grey circles indicate those participants with low sensitivity to musical reward (below -1.5 SD from the mean) but normal scores in the anhedonia scale (between $+/-1.5$ SD from the mean). This population represents $5.6 \%$ of the (a) first sample ( $n=804$ ) and the $5.5 \%$ of the $(\mathrm{b})$ third sample $(n=252)$.

of musical anhedonia (Griffiths, Warren, Dean, \& Howard, 2004; Mazzoni et al., 1993; Satoh, Nakase, Nagata, \& Tomimoto, 2011). The lesions observed in these cases comprised the right temporo-parietal (Mazzoni et al., 1993) and parietal cortex (Satoh et al., 2011) and the left insular cortex extending to the amygdala (Griffiths et al., 2004; see also Gosselin et al., 2006, for the implication of amygdala in emotion processing of music). Interestingly, this reduced capacity to experience emotions with music could indeed be accompanied by a preserved perception of emotions that music could induce. The reverse pattern of preserved emotional experience but altered emotion perception has also been reported (see Matthews, Chang, De May, Engstrom, \& Miller, 2009), suggesting at least partial independence of both processes. We believe that the identification of otherwise healthy musical anhedonic individuals might be crucial for understanding how our brain decodes emotion from music listening and performance. This approximation may be very useful to study the neural basis of emotion and pleasure in music rewarding experiences.

One important practical issue regarding the administration of this questionnaire in further research is that when using the scores of the five different facets identified, and mostly due to the small number of items composing each factor, it is advisable to use the factor scores estimate instead of the raw addition of items of each subscale (Ferrando, 2012). The factor score estimate is a measure in which acquiescence responding is controlled (for the computation of factors scores, visit www.brainvitge.org/bmrq.php) increasing the reliability of the facet. However, to obtain an overall measure of music reward, the raw-addition score of all the items of the BMRQ might be an appropriate estimate of the music reward tendency of each individual. Thus, if the aim is to use an overall measure of the BMRQ, the overall rawaddition score could be used. For more fine-grained analysis on the specific facets we advise to use factor scores estimates.

\section{Author Note}

We want to thank our participants and colleagues for their help and collaboration with the present project. In addition, we want to especially thank Pere Poch for his help in the construction of the internet platform. This project has been supported by the following funds: 
Predoctoral grant to E. M. H. (MICINN), Ramon y Cajal position awarded to J. M. P., Spanish grants MICINN (PSI2011-29219 - A. R. F. and PSI200909101 - J. M. P.), the Catalan Government (Generalitat de Catalunya, 2009 SGR 93) and a grant for Visiting Researchers of the Spanish Government to R. Z.
Correspondence concerning this article should be addressed to Ernest Mas-Herrero \& Antoni RodriguezFornells, Cognition and Brain Plasticity Group [Bellvitge Biomedical Research Institute-] IDIBELL, L'Hospitalet de Llobregat, Barcelona 08097, Spain. E-mail: ernest_mas @hotmail.com | arfornells@gmail.com

\section{References}

Altenmüller, E., Schürmann, K., Lim, V. K., \& Parlitz, D. (2002). Hits to the left, flops to the right: Different emotions during listening to music are reflected in cortical lateralisation patterns. Neuropsychologia, 40, 2242-2256.

Ayotte, J., Peretz, I., \& Hyde, K. (2002). Congenital amusia: A group study of adults afflicted with a music-specific disorder. Brain, 125, 238-251.

Baumgartner, T., Esslen, M., \& Jäncke, L. (2006). From emotion perception to emotion experience: Emotions evoked by pictures and classical music. International Journal of Psychophysiology, 60, 34-43.

Becker, J. (2004). Deep listeners: Music, emotion, and trancing. Bloomington, IN: Indiana University Press.

Benne, K.-E. (1997). The development of Musikerleben in adolescence: How and why young people listen to music. In I. Deliège \& J. A. Sloboda (Eds.), Perception and cognition of music (pp. 143-159). Hove, UK: Psychology Press.

Berridge, K. C., \& Kringelbach, M. L. (2008). Affective neuroscience of pleasure: Eeward in humans and animals. Psychopharmacology, 199, 457-480.

Blood, A. J., \& Zatorre, R. J. (2001). Intensely pleasurable responses to music correlate with activity in brain regions implicated in reward and emotion. Proceedings of the National Academy of Sciences of the United States of America, 98, 11818-11823.

Boer, D., Fischer, R., Strack, M., Bond, M. H., Lo, E., \& LAM, J. (2011). How shared preferences in music create bonds between people: Values as the missing link. Personality and Social Psychology Bulletin, 37, 1159-1171.

Bradt, J., Magee, W. L., Dileo, C., Wheeler, B. L., \& McGilloway, E. (2010). Music therapy for acquired brain injury. Cochrane Database of Systematic Reviews, 7, CD006787.

Brown, S., Martinez, M. J., \& Parsons, L. M. (2004). Passive music listening spontaneously engages limbic and paralimbic systems. Neuroreport, 15, 2033-2037.

Brown, S., Martinez, M. J., \& Parsons, L. M. (2006). The neural basis of human dance. Cerebral Cortex, 16, 1157-1167.

Browne, M. W. (1972). Oblique rotation to a partially specified target. British Journal of Mathematical and Statistical Psychology, 25, 207-212.

Bruner, G. C. (1990). Music, mood, and marketing. The Journal of Marketing, 54, 94-104.
Camara, E., Rodriguez-Fornells, A., Ye, Z., Munte, T. F. (2009). Reward networks in the brain as captured by connectivity measures. Frontiers in Neuroscience, 3, 350-362.

Carver, C. S., \& White, T. L. (1994). Behavioral inhibition, behavioral activation, and affective responses to impending reward and punishment: The BIS/BAS Scales. Journal of Personality and Social Psychology, 67, 319-333.

Caseras, X., Ávila, C., \& Torrubia, R. (2003). The measurement of individual differences in behavioral inhibition and behavioral activation systems: A comparison of personality scales. Personality and Individual Differences, 34, 999-1013.

Chamorro-Premuzic, T., \& Furnham, A. (2007). Personality and music: Can traits explain how people use music in everyday life? British Journal of Psychology, 98, 175-185.

Chapman, L. J., Chapman, J. P., \& Raulin, M. L. (1976). Scales for physical and social anhedonia. Journal of Abnormal psychology, 85, 374-382.

Chin, T., \& Rickard, N. S. (2012). The Music USE (MUSE) questionnaire: An instrument to measure engagement in music. Music Perception, 29, 429-446.

Cohen, A. J. (2001). Music as a source of emotion in film. In P. N. Juslin \& J. A. Sloboda (Eds.), Music and emotion: Theory and research (pp. 249-272). New York: Oxford University Press.

Costa, P. T., McCrae, R. R. (1992). Revised NEO Personality Inventory (NEO-PI-R) and NEO Five-Factor Inventory (NEOFFI) professional manual. Odessa, FL: Psychological Assessment Resources, Inc.

Costa, P. T., Terracciano, A., \& McCrae, R. R. (2001). Gender differences in personality traits across cultures: Robust and surprising findings. Journal of Personality and Social Psychology, 81, 322-331.

Cross, I. (2001). Music, cognition, culture, and evolution. Annals of the New York Academy of Sciences, 930, 28-42.

Cross, I., \& Morley, I. (2009). The evolution of music: Theories, definitions and the nature of the evidence. In S. Malloch \& C. Trevarthen (Eds.), Communicative musicality (pp. 61-82). Oxford, UK: Oxford University Press.

Deci, E. L., Koestner, R., \& Ryan, R. M. (1999). A metaanalytic review of experiments examining the effect of extrinsic rewards on intrinsic motivation. Psychological Bulletin, 125, 627-668. 
Dellacherie, D., Ehrlé, N., \& Samson, S. (2008). Is the neutral condition relevant to study musical emotion in patients? Music Perception: An Interdisciplinary Journal, 25, 285-294.

DeNora, T. (1999). Music as a technology of the self. Poetics, 27, 31-56.

Dubé, L., \& LE BeL, J. (2003). The content and structure of laypeople's concept of pleasure. Cognition and Emotion, 17, 263-295.

Farnell, B. (1999). Moving bodies, acting selves. Annual Review of Anthropology, 28, 341-373.

Ferrando, P. J. (2012). Assessing the discriminating power of item and test scores in the linear factor-analysis model. Psicologica, 33, 111-134.

Ferrando, P. J., \& Lorenzo, U. (2000). Unrestricted versus restricted factor analysis of multidimensional test items: Some aspects of the problem and some suggestions. Psicologica, 21, 301-323.

Ferrando, P. J., Lorenzo-Seva, U., \& Chico, E. (2009). A general factor analytic procedure for assessing response bias in questionnaire measures. Structural Equation Modeling, 16, 364-381.

Fonseca-Pedrero, E., Paino, M., Lemos-Giráldez, S., García-Cueto, W., Villazón-García, U., Bobes, J., \& Muñiz, J. (2009). Psychometric properties of the revised physical and social anhedonia scales in non-clinical young adults. The Spanish Journal of Psychology, 12, 815-822.

Freeman, W. J. (2000). A neurobiological role of music in social bonding. In N. Wallin, B. Merker, \& S. Brown (Eds.), The origins of music (pp. 411-424). Cambridge, MA: MIT Press.

Gabrielsson, A. (2001). Emotions in strong experiences with music. In P. N. Juslin \& J. A. Sloboda (Eds.), Music and emotion: Theory and research (pp. 431-449). New York: Oxford University Press.

Gabrielsson, A. (2010). Strong experiences with music. In P. N. Juslin \& J. A. Sloboda (Eds.), Handbook of music and emotion (pp. 547-574). Oxford, UK: Oxford University Press.

Gabrielsson, A. (2011). How do strong experiences with music relate to experiences in everyday listening to music? In I.

Deliège \& J. W. Davidson (Eds.), Music and the mind. Essays in honour of John Sloboda (pp. 91-110). Oxford, UK: Oxford University Press.

Gabrielsson, A., \& Juslin, P. N. (2003). Emotional expression in music. In R. J. Davidson, K. R. Scherer, \& H. H. Goldsmith (Eds.), Handbook of affective sciences (pp. 503-534). New York: Oxford University Press.

Gosselin, N., Peretz, I., Noulhiane, M., Hasboun, D., Beckett, C., Baulac, M., \& SAmson, S. (2005). Impaired recognition of scary music following unilateral temporal lobe excision. Brain, 128, 628-640.
Gosselin, N., Samson, S., Adolphs, R., Noulhiane, M., Roy, M., Hasboun, D., Et Al. (2006). Emotional responses to unpleasant music correlates with damage to the parahippocampal cortex. Brain, 129, 2585-2592.

Gray, J. A. (1990). Brain systems that mediate both emotion and cognition. Cognition and Emotion, 4, 269-288.

Griffiths, T. D., Warren, J. D., Dean, J. L., \& Howard, D. (2004). When the feeling's gone: A selective loss of musical emotion. Journal of Neurology, Neurosurgery, and Psychiatry, 75, 344-345.

Guetin, S., Portet, F., Picot, M.-C., Defez, C., Pose, C., Blayac, J.-P., \& Touchon, J. (2009). Impact of music therapy on anxiety and depression for patients with Alzheimer's disease and on the burden felt by the main caregiver. L'Encéphale, 35, 57-65.

Gupta, U., \& Gupta, B. S. (2005). Psychophysiological responsivity to Indian instrumental music. Psychology of Music, 33, 363-372.

Hargreaves, D. J., \& Colman, A. M. (1981). The dimensions of aesthetic reactions to music. Psychology of Music, 9, 15-20.

Harmat, L., Takács, J., \& Bódizs, R. (2008). Music improves sleep quality in students. Journal of Advanced Nursing, 62, 327-335.

Huron, D. (2009). Aesthetics. In S. Hallam, I. Cross, \& M. Thaut (Eds.), The Oxford handbook of music psychology (pp. 151-159). Oxford, UK: Oxford University Press.

Joreskog, K., \& Sorbom, D. (2001). LISREL 8.5: User's Reference Guide. Chicago, IL: Scientific Software International.

Jorm, A., Christensen, H., Henderson, A., Jacomb, P., Korten, A., \& Rodgers, B. (1998). Using the BIS/BAS scales to measure behavioural inhibition and behavioural activation: Factor structure, validity and norms in a large community sample. Personality and Individual Differences, 26, 49-58.

Juslin, P. N., \& Laukka, P. (2003). Emotional expression in speech and music: Evidence of cross-modal similarities. Annals of the New York Academy of Sciences, 1000, 279-282.

Juslin, P. N., \& LaukKa, P. (2004). Expression, perception, and induction of musical emotions: A review and a questionnaire study of everyday listening. Journal of New Music Research, 33, 17-38.

Juslin, P. N., Liljeström, S., Västfjäll, D., Barradas, G., \& Silva, A. (2008). An experience sampling study of emotional reactions to music: Listener, music, and situation. Emotion, 8 , 668-683.

Juslin, P. N., \& VÄstfjäll, D. (2008). Emotional responses to music: The need to consider underlying mechanisms. The Behavioral and Brain Sciences, 31, 559-575.

KaIser H. F. (1970). A second generation of Little Jiffy. Psychometrika, 35, 401-415.

KAiser, H. F., \& Rice, J. (1974). Little Jiffy, Mark IV. Educational and Psychological Measurement, 34, 111-117.

Katz, E., Blumer, J. G., \& Gurevitch, M. (1974). Uses and gratifications research. Public Opinion Quarterly, 37, 509-523. 
Khalfa, S., Roy, M., Rainville, P., Dalla Bella, S., \& Peretz, I. (2008). Role of tempo entrainment in psychophysiological differentiation of happy and sad music? International Journal of Psychophysiology, 68, 17-26.

Knobloch, S., Vorderer, P., \& Zillmann, D. (2000). Der Einfluß des Musikgeschmacks auf die Wahrnehmung möglicher Freunde im Jugendalter [The impact of music preferences on the perception of potentials friends in adolescence].

Zeitschrift für Sozialpsychologie, 31, 18-30.

Koelsch, S., Fritz, T., Müller, K., Friederici, A. D. (2006). Investigating emotion with music: An fMRI study. Human Brain Mapping, 27, 239-250.

Koelsch, S. (2010). Towards a neural basis of music-evoked emotions. Trends in Cognitive Science, 14, 131-137.

Krumhansl, C. L. (1997). An exploratory study of musical emotions and psychophysiology. Canadian Journal of Experimental Psychology, 51, 336-353.

Laukka, P. (2007). Uses of music and psychological well-being among the elderly. Journal of Happiness Studies, 8, 215-241.

Lonsdale, A. J., \& North, A. C. (2009). Musical taste and ingroup favouritism. Group Processes and Intergroup Relations, 12, 319-327.

Lonsdale, A. J., \& North, A. C. (2011). Why do we listen to music? A uses and gratifications analysis. British Journal of Psychology, 102, 108-134.

Lorenzo-Seva, U., \& Ferrando, P. J. (2006). FACTOR: A computer program to fit the Exploratory Factor Analysis model. Behavior Research Methods, Instruments, and Computers, 38, 88-91.

Lorenzo-Seva, U., \& Ferrando, P. J. (2009). Acquiescent responding in partially balanced multidimensional scales. British Journal of Mathematical and Statistical Psychology, 62, 319-326.

Lorenzo-Seva, U., \& ten Berge, J. M. F. T. (2006). Tucker's congruence coefficient as a meaningful index of factor similarity. Methodology, 2, 57-64.

Lorenzo-Seva, U., \& Rodríguez-Fornells, A. (2006). Acquiescent responding in balanced multidimensional scales and exploratory factor analysis. Psychometrika, 71, 769-777.

Matthews, B. R., Chang, C.-C., De May, M., Engstrom, J., \& Miller, B. L. (2009). Pleasurable emotional response to music: A case of neurodegenerative generalized auditory agnosia. Neurocase, 15, 248-259.

Mazzoni, M., Moretti, P., Pardossi, L., Vista, M., Muratorio, A., \& Puglioli, M. (1993). A case of music imperception. Journal of Neurology, Neurosurgery, and Psychiatry, 56, 322.

McCrae, R. R. (2007). Aesthetic chills as a universal marker of openness to experience. Motivation and Emotion, 31, 5-11.
Mellenbergh, G. J. (1994). A unidimensional latent trait model for continuous item responses. Multivariate Behavioral Research, 29, 223-236.

Menon, V., \& Levitin, D. J. (2005). The rewards of music listening: Response and physiological connectivity of the mesolimbic system. NeuroImage, 28, 175-184.

Miller, G. F. (2000). Evolution of human music through sexual selection. In N. L. Wallin B. Merker, \& S. Brown (Eds.), The origins of music (pp. 329-360). Cambridge, MA: MIT Press

Mithen, S. (2005). The singing Neanderthals: The origins of music, language, mind and body. London, UK: Weidenfeld and Nicholson.

Mitterschiffthaler, M. T., Fu, C. H. Y., Dalton, J. A., Andrew, C. M., \& Williams, S. C. R. (2007). A functional MRI study of happy and sad affective states induced by classical music. Human Brain Mapping, 28, 1150-1162.

North, A. C., \& Hargreaves, D. J. (2007a). Lifestyle correlates of musical preference: 1 . Relationships, living arrangements, beliefs, and crime. Psychology of Music, 35, 58-87.

North, A. C., \& Hargreaves, D. J. (2007b). Lifestyle correlates of musical preference: 2. Media, leisure time and music. Psychology of Music, 35, 179-200.

North, A. C., \& Hargreaves, D. J. (2007c). Lifestyle correlates of musical preference: 3. Travel, money, education, employment and health. Psychology of Music, 35, 473-497.

North, A. C., Hargreaves, D. J., \& O’Neill, S. A. (2000). The importance of music to adolescents. British Journal of Educational Psychology, 70, 255-272.

NourIs, M. J. (1999). SPSS for Windows 9.0. Chicago, IL: SPSS Inc. Nusbaum, E. C., \& Silvia, P. J. (2010). Shivers and timbres: Personality and the experience of chills from music. Social Psychological and Personality Science, 2, 199-204.

Panksepp, J., \& Bernatzky, G. (2002). Emotional sounds and the brain: The neuro-affective foundations of musical appreciation. Behavioural Processes, 60, 133-155.

Pelletier, C. L. (2004). The effect of music on decreasing arousal due to stress: A meta-analysis. Journal of Music Therapy, 41, 192-214.

Rentfrow, P. J., \& Gosling, S. D. (2003). The do re mi's of everyday life: The structure and personality correlates of music preferences. Journal of Personality and Social Psychology, 84, 1236-1256.

Rentfrow, P. J., \& McDonald, J. A. (2010). Preference, personality, and emotion. In P. N. Juslin \& J. A. Sloboda (Eds.), Handbook of music and emotion: Theory, research, applications (pp. 669-695). Oxford, UK: Oxford University Press.

Rodriguez-Fornells, A., Rojo, N., Amengual, J. L., Ripollés, P., Altenmüller, E., \& Münte, T. F. (2012). The involvement of audio-motor coupling in the music-supported therapy applied to stroke patients. Annals of the New York Academy of Sciences, 1252, 282-293. 
Rojo, N., Amengual, J., Juncadella, M., Rubio, F., Camara, E., Marco-Pallares, J., ET Al. (2011). Music-supported therapy induces plasticity in the sensorimotor cortex in chronic stroke: A single-case study using multimodal imaging (fMRI-TMS). Brain Injury, 25, 787-793.

Romero, E., Luengo, M.A., Gómez-Fraguela, J. A., \& Sobral, J. (2002). La estructura de los rasgos de personalidad en adolescentes: El Modelo de Cinco Factores y los Cinco Alternativos [The structure of personality traits in adolescents: The FiveFactor Model and the Alternative Five]. Psicotema, 14, 134-143.

Rowe, G., Hirsh, J. B., \& Anderson, A. K. (2007). Positive affect increases the breadth of attentional selection.

Proceedings of the National Academy of Sciences of the United States of America, 104, 383-388.

Salimpoor, V. N., Benovoy, M., Larcher, K., Dagher, A., \& Zatorre, R. J. (2011). Anatomically distinct dopamine release during anticipation and experience of peak emotion to music. Nature neuroscience, 14, 257-262.

Salimpoor, V. N., Benovoy, M., Longo, G., Cooperstock, J. R., \& Zatorre, R. J. (2009). The rewarding aspects of music listening are related to degree of emotional arousal. PloS One, 4, e7487.

Sammler, D., Grigutsch, M., Fritz, T., \& Koelsch, S. (2007). Music and emotion: Electrophysiological correlates of the processing of pleasant and unpleasant music. Psychophysiology, 44, 293-304.

Särkämö, T., Tervaniemi, M., Laitinen, S., Forsblom, A., Soinila, S., Mikkonen, M., et Al. (2008). Music listening enhances cognitive recovery and mood after middle cerebral artery stroke. Brain, 131, 866-876.

Satoh, M., Nakase, T., Nagata, K., \& Tомimoto, H. (2011). Musical anhedonia: Selective loss of emotional experience in listening to music. Neurocase, 17, 410-417.

Schellenberg, E. G. (2003). Does exposure to music have beneficial side effects? In I. Peretz \& R. J. Zatorre (Eds.), The cognitive neuroscience of music (pp. 430-448). Oxford, UK: Oxford University Press.

Schneider, S., Schönle, P. W., Altenmüller, E., \& Münte, T. F. (2007). Using musical instruments to improve motor skill recovery following a stroke. Journal of Neurology, 254, 1339-1346.

Selfhout, M. H. W., Branje, S. J. T., ter Bogt, T. F. M., \& Meeus, W. H. J. (2009). The role of music preferences in early adolescents' friendship formation and stability. Journal of Adolescence, 32, 95-107.

Sloboda, J. A. (1992). Empirical studies of emotional response to music. In M. R. Jones \& S. Holleran (Eds.), Cognitive bases of musical communication (pp. 33-46). Washington, DC:

American Psychological Association.

Sloboda, J. A. (1999). Everyday uses of music listening: A preliminary study. In Y. I. Suk Won (Ed.), Music, mind and science (pp. 354-369). Seoul, Korea: Seoul National University Press.
Sloboda, J. A. (2005). Exploring the musical mind. New York: Oxford University Press.

Sloboda, J. A. (2010). Music in everyday life: The role of emotions. In P. N. Juslin \& J. A. Sloboda (Eds.), Handbook of music and emotion: Theory, research, applications (pp. 493-514). New York: Oxford University Press.

Sloboda, J. A., \& Juslin, P. N. (2001). Psychological perspectives on music and emotion. In P. N. Juslin \& J. A. Sloboda (Eds.), Music and emotion: Theory and research (pp. 71-104). New York: Oxford University Press.

Sloboda, J. A., Lamont, A., \& Greasley, A. (2009). Choosing to hear music: Motivation, process and effect. In S. Hallam, I. Cross, \& M. Thaut (Eds.), The Oxford handbook of music psychology (pp. 431-440). Oxford, UK: Oxford University Press.

Sloboda, J. A., \& O’Neill, S. A. (2001). Emotions in everyday listening to music. In P. N. Juslin \& J. A. Sloboda (Eds.), Music and emotion: Theory and research (pp. 415-429). New York: Oxford University Press.

Snee, R. D. (1977). Computer aided design of experiments. Technometrics, 19, 415-428.

Soto, D., Funes, M. J., Guzmán-García, A., Warbrick, T., Rotshtein, P., \& Humphreys, G. W. (2009). Pleasant music overcomes the loss of awareness in patients with visual neglect. Proceedings of the National Academy of Sciences of the United States of America, 106, 6011-6016.

Tarrant, M., North, A. C., \& Hargreaves, D. J. (2000). English and American adolescents' reasons for listening to music. Psychology of Music, 28, 166-173.

ten Berge, J. M. F., Krijnen, W., Wansbeek, T., \& Shapiro, A. (1999). Some new results on correlation-preserving factor scores prediction methods. Linear Algebra and its Applications, 289, 311-318.

ten Berge, J. M. F., \& Kiers, H. A. L. (1991).

A numerical approach to the approximate and the exact minimum rank of a covariance matrix. Psychometrika, 56, 309-315.

Torrubia, R., Ávila, C., Moltó, J., \& Caseras, X. (2001). The Sensitivity to Punishment and Sensitivity to Reward Questionnaire (SPSRQ) as a measure of Gray's anxiety and impulsivity dimensions. Personality and Individual Differences, 31, 837-862.

Weisberg, Y. J., Deyoung, C. G., \& Hirsh, J. B. (2011). Gender differences in personality across the ten aspects of the Big Five. Frontiers in Psychology, 2, 178.

Wells, A., \& Hakanen, E. A. (1991). The emotional use of popular music by adolescents. Journalism Quarterly, 68, 445-454.

Werner, P. D., Swope, A. J., \& Heide, F. J. (2006). The music experience questionnaire: Development and correlates. The Journal of Psychology, 140, 329-345. 
Whaley, J., Sloboda, J. A., \& Gabrielsson, A. (2009). Peak experiences in music. In S. Hallam, I. Cross, \& M. Thaut (Eds.), The Oxford handbook of music psychology (pp. 452-461). Oxford, UK: Oxford University Press.

ZAlD, D. H., \& Zatorre R. J. (2011). Music. In J. A. Gottfried (Ed.), Neurobiology of sensation and reward (pp. 405-428). Boca Raton, FL: CRC Press.
Zatorre, R. J., Chen, J. L., \& Penhune, V. B. (2007). When the brain plays music: Auditory-motor interactions in music perception and production. Nature reviews. Neuroscience, 8 , 547558.

ZillmanN, D., \& GAN, S. (1997). Musical taste in adolescence. In D. J. Hargreaves \& A. C. North (Eds.), The social psychology of music (pp. 161-187). New York: Oxford University Press.

\section{Appendix A. BMRQ version in Spanish}

El siguiente cuestionario hace preguntas sobre tus actitudes en relación a la música. Cada ítem de este cuestionario es una afirmación con la que se puede estar de acuerdo o en desacuerdo. Para cada ítem, indica en qué grado estás de acuerdo o en desacuerdo con lo que dice el ítem. Por favor, responde a todos los ítems y no dejes ninguno en blanco. Escoge sólo una respuesta para cada afirmación. Por favor, intenta ser lo más preciso y honesto, respondiendo a cada ítem como si fuera el único. Es decir, no te preocupes en ser "consistente" en tus respuestas. Escoge entre las siguientes opciones:

[1] - completamente en desacuerdo; [2] - en desacuerdo; [3] - ni de acuerdo ni en desacuerdo; [4] - de acuerdo; [5] completamente de acuerdo.

1. Cuando comparto música con alguien siento una complicidad especial con aquella persona.

2. En mi tiempo libre apenas escucho música.

3. Algunas canciones me ponen los pelos de punta.

4. La música me hace compañía cuando estoy solo.

5. No me apetece bailar ni con la música que más me gusta.

6. La música me hace conectar con la gente.

7. Me informo sobre la música que me gusta.

8. Me emociono escuchando ciertas canciones.

9. La música me tranquiliza y me relaja.

10. La música me hace bailar.

11. Busco novedades musicales continuamente.

12. Puedo llorar cuando escucho algunas melodías que me gustan mucho.

13. Me gusta cantar o tocar un instrumento con más gente.

14. La música me ayuda a desconectar.

15. No puedo evitar tararear las canciones que me gustan cuando las escucho.

16. En los conciertos me siento en sintonía con los artistas y el público.

17. Me gasto bastante dinero en música y cosas relacionadas con la música.

18. Siento escalofríos cuando escucho una melodía que me gusta.

19. Con la música me puedo desahogar.

20. Cuando escucho una melodía que me gusta mucho no puedo evitar mover el cuerpo.

\section{Appendix B. BMRQ version in English}

Each item of this questionnaire is a statement that a person may either agree with or disagree with. For each item, indicate how much you agree or disagree with what the item says. Please respond to all the items; do not leave any blank. Choose only one response to each statement. Please be as accurate and honest as you can be. Respond to each item as if it were the only item. That is, do not worry about being consistent in your responses. Choose from completely disagree (left) to completely agree (right) one of the five options:

[1] - Completely disagree; [2] - disagree; [3] - Neither agree nor disagree; [4] - agree; [5] Completely agree.

1. When I share music with someone I feel a special connection with that person.

2. In my free time I hardly listen to music.

3. I like listen to music that contains emotion. 
4. Music keeps me company when I'm alone.

5. I don't like to dance, not even with music I like.

6. Music makes me bond with other people.

7. I inform myself about music I like.

8. I get emotional listening to certain pieces of music.

9. Music calms and relaxes me.

10. Music often makes me dance.

11. I'm always looking for new music.

12. I can become tearful or cry when I listen to a melody that I like very much.

13. I like to sing or play an instrument with other people.

14. Music helps me chill out.

15. I can't help humming or singing along to music that I like.

16. At a concert I feel connected to the performers and the audience.

17. I spend quite a bit of money on music and related items.

18. I sometimes feel chills when I hear a melody that I like.

19. Music comforts me.

20. When I hear a tune I like a lot I can't help tapping or moving to its beat. 